\title{
Editorial
}

\section{Views of childhood and knowledge of children}

In a country where there is a consistent loud outcry about school achievement of youth in the final school examination in Grade 12, attention has recently shifted to children in the primary school. The very founding of this journal was motivated by a deep concern about research in childhood education and children's lives. Questions were being asked about what happens in the first years of schooling, about the suitability of the national curriculum for such a diverse population, about specialised research in the field of learning in the early years, and about teaching with care and with insight, knowing who the children of this nation are.

The journal took an early stand when, at its launch in 2010, the editor noted that the notion of a national foundation phase curriculum assumes the existence of a 'national' Grade 1 learner. In South Africa there are children who come to school, well prepared for the demands of school - and there are others who come with only their survival records in homes of extreme poverty, of absent parents and of families broken by the effects of the history of the nation and the effects of disease. Much as we would like to see a standard of performance expected from the 'national' young learner, we need to see the layers of diversity too. Can such a stratified population, socially fractured in many ways, truly enact a differentiated curriculum for children who have so much and for children who have so little at the same time and at the same pace? Can our foundation phase classes be truly inclusive?

It remains a vexing question. Much research is needed to even try to give a robust response. In recent years, in the research of the Centre for Education Practice Research at my home institution, we have encountered more than 3000 children between five and seven years old in an extensive interview test of mathematical cognition. In the process we found children who had never encountered a print drawing and children who did not know that a page can be turned. However, the very same children had a perfectly normal idea of approximate number and size. We regard this as evidence that they have the core knowledge of number that has to be developed by systematic instruction and caring apprenticeship in classrooms. But for that they would need teachers who know them as well as they know the latest curriculum and its suggested tools of teaching.

This is but one example of how important teacher education is and how important it is that we should investigate both learners and teachers, but also teacher education and teacher educators. Teachers and their educators at universities have their own view of children, of learning and of childhood. Much as we may all agree that the core activity of schools is for the young to learn the three Rs and the subject areas of the curriculum, there are researchers who are opposed to a developmental view of learning. The journal's stance is that, in the Vygotskian tradition (Kozulin, 1990), the young learn and are initiated - and thus develop - in the work of school (and society). 
In the SAJCE we welcome different views on child learning and celebrate South Africa's researchers who argue that "pedagogical 'know-how' and views of child and childhood constitute the subject knowledge that is foundational in the foundation phase curriculum" - as Murris and Verbeek do in this issue. Add to that knowledge of how children the world over have core knowledge systems, as argued by cognitive developmental psychologists and neuroscientists, and we have a composite picture of what the object of teacher education is - to know 1) the learner and 2) the subject content, but also 3) the self as teacher.

This 'didactical triangle', was already proposed as view of teaching in the $17^{\text {th }}$ century in Comenius's major work, Didactica Magna (Comenius, 1632/1967). In the $20^{\text {th }}$ century, for some reason, the English- speaking world used the term 'didactic' to denote teacher-centred learning, while Comenius proposed what can arguably nowadays be termed pedagogical content knowledge (PCK). Jari Lavonen, the chair of the teacher education department at the University of Helsinki, recently noted that PCK is the transformation of subject content knowledge by infusing it with knowledge of the learner and of the self as teacher. In Finland they refer to PCK simply as Didactics, while taking full cognisance of Shulman's model (Shulman 1986).

But, views on teaching become more complicated when teachers are faced with children who enter Grade 1, but who are not ready to embrace the way of life at school. Bruwer and her co-authors report in this issue on teachers' views on the predicament they face when children need to cross the liminality boundary - when they are still 'betwixt and between' life as an informal learner and life in school, where they have to be inducted into life as a formal learner in a national curriculum. In the same vein, Condy and Blease argue that a "one-size-fits-all curriculum cannot address the issues that rural multigrade teachers and learners face". Seldom do educational researchers contemplate this very real issue. I was in the same class in Grade 1 as my brother, who was then in Grade 8, in a little farm school. I recall vividly how we young ones spent much time making clay oxen while they were doing indecipherable maths on the writing board.

When more than one language is used, or required to be used, in a single classroom communication set-up, a teacher is faced with yet another dimension. Ankiah-Gangadeen and Samuel write about a narrative inquiry that was conducted in Mauritius, noting that the "narrative inquiry methodology offered rich possibilities to foray into these [teachers'] experiences, including the manifestations of negotiating their classroom pedagogy in relation to their own personal historical biographies of language teaching and learning".

Added to the multilayered types of knowledge around which a teacher needs to negotiate her way in a foundation phase classroom, are knowledge and understanding of children's transition from one grade to the next. Nieuwenhuizen and co-authors found that the move from Grade 2 to Grade 3 is notably more difficult for children than earlier grade transitions. I wish to add that it is also a grade transition that requires much more of the learning child in volume and in pace of learning; the transition 
requires a 'mature' young learner who has worked through the curriculum of the earlier grades effectively.

Kanjee and Moloi not only present information about ANA results, but show how teachers utilise these in their teaching. To that, the editorial team adds: what is the national testing ritual really doing for teachers? Are there many unforeseen and even unintended effects? Many teachers may say that it alerts them to gaps in their own knowledge and pedagogy and, especially, we would think, the way in which they assess children's learning effectively. While Kanjee and Moloi invoke local national tests, Fritz and her co-authors from Germany, Switzerland and South Africa show how a mathematics competence and diagnostic test for school beginners found its way from Europe to South Africa. They point to the challenges of translating an interview-based test and of validating it in a local context in four languages. With the promise that the test will be normed in this country, the foundation phase education as well as the educational psychology community may stand to benefit from such a test, which is theoretically grounded in children's conceptual development.

The matter of teaching with formative assessment as pedagogical tool comes to mind whenever one discusses assessment. In an article by Long and Dunne, one reads about their investigation into teaching of mathematics with a very specific angle - how to "map and manage the omissions implicit in the current unfolding of the Curriculum and Assessment Policy Statement (CAPS) for mathematics". In a very dense and fast paced curriculum it is not possible to fill all the gaps. Who knows what the effect may be for future learning of children who move through a curriculum quite rapidly?

Staying in the early grade classroom, Sibanda explores the readability of two textbooks for natural science learning for Grade 4 learners. She touches on one of the sensitive nerves of South African school education, namely the English language. In her analysis of two textbooks, using a range of methods of text analysis, she comes to the conclusion that the books are simply too difficult to read. She argues that the authors have not taken into account that both vocabulary and syntax have to be taught systematically in order for Grade 4 children to be able to read texts in a language they do not know well, for one, and in a discourse of science writing that is new for them as well.

Ragpot narrates the story of how an instructional film, \#Taximaths: how children make their world mathematical, was conceptualised, scripted and produced with senior undergraduate students at UJ. This artefact serves not only as higher education material in teacher education, but is also used as material for teacher development. ${ }^{1}$

This issue of the journal is rounded off by an important contribution about the ethics of research on children. Pillay explains how experts in ethics have advised him in the work they do in the National Research Foundation South African Research Chair he holds in 'Education and Care in Childhood' at the University of Johannesburg. The reader is reminded that care of vulnerable children and the protection of their rights should be high on the list of educational practice and its research. 
The next issue of SAJCE is a special one. It is edited by Nadine Petersen and Sarah Gravett and it celebrates a programme of research and development of the South African Department of Higher Education and Training, with funding support from the EU. The Strengthening Foundation Phase Teacher Education Programme started in 2011 and included most of the universities in the country. The issue promises to be a milestone publication on teacher education for the primary school.

Editorial greetings

Elizabeth Henning

\section{References}

Comenius JA.1632; 1967. The Great Didactic. MW Keatinge (transl and annot). London: Adam and Charles Black.

Kozulin, A. 1990. Vygotsky's psychology: A biography of ideas. Cambridge, MA: Harvard.

Shulman LS. 1986. Those who understand. Knowledge growth in teaching. Educational Researcher, 15(2):4-14.

\section{Endnotes}

1. See the trailer at https://www.youtube.com/watch?v=x3VZVF4UsoQ 